ISSN: 1829-6750 Inovasi Kurikulum, Agustus 2009, Thn. 6 . Vol 6 Nomor: 2

\title{
EVALUASI IMPLEMENTASI KURIKULUM TINGKAT SATUAN PENDIDIKAN (KTSP) SEKOLAH MENENGAH ATAS
}

\section{Azis}

Abstrak: Pengembangan kurikulum yang sejalan dengan sistem pendidikan nasional, kebutuhan dan kondisi riil perlu diupayakan secara terus menerus bagi terwujudnya sumber daya manusia yang handal. Dengan digunakannya kurikulum 2006 (KTSP), perubahan kurikulum 2004 ke 2006, merupakan upaya pembaharuan atau penyesuaian kurikulum yang didasarkan pada standar isi dan standar kompetensi lulusan yang diharapkan sejalan dengan kebutuhan masyarakat. Untuk KTSP tingkat pendidikan menengah (SMA), tujuan pendidikannya adalah meningkatkan kecerdasan, pengetahuan, kepribadian, akhlak mulia, serta keterampilan untuk hidup mandiri, dan dapat mengikuti pendidikan lebih lanjut. Untuk mencapai tujuan tersebut, dijabarkan ke dalam sejumlah mata pelajaran yang terdapat pada jenjang pendidikan menengah. Pada tataran implementasi kurikulum secara umum, implementasi KTSP meliputi pengembangan silabus dan RPP, pelaksanaan proses pembelajaran dan cara penilaiannya. Dalam konteks pelaksanaan kurikulum, hasil penilaian dapat diamati melalui indikator-indikator yang tercermin dalam rangkaian kegiatan pembelajaran, sebagai bentuk implementasi kurikulum. Untuk melihat sejauhmana keberhasilan dari implementasi kurikulum, sudah barang tentu membutuhkan waktu dan proses, karena hasil dari suatu proses pembelajaran merupakan rangkaian kegiatan yang terus menerus dan panjang.

Kata kunci: Evaluasi, implementasi kurikulum, KTSP 
ISSN: 1829-6750 Inovasi Kurikulum, Agustus 2009, Thn. 6. Vol 6 Nomor: 2

\section{A. Pendahuluan}

Sebelum masuk pada persoalan pokok dari makalah ini, terlebih dahulu perlu dijelaskan sepintas mengenai pengertian kurikulum sebagai landasan untuk pembahasan selanjutnya. Pengertian kurikulum yang paling umum adalah seperangkat mata pelajaran yang ditetapkan untuk diajarkan di sekolah. Seringkali pula kurikulum diartikan sebagai materi atau bahan pelajaran dalam buku teks yang ditetapkan atau ditawarkan untuk diajarkan guru.

Pengertian kurikulum ini begitu banyak dianut oleh orang awam, bahkan oleh banyak pendidik, sehingga jika berbicara tentang kurikulum (termasuk pengembangannya), mereka mengasosiasikannya dengan mata pelajaran atau materi pelajaran. Seiring dengan itu, pedoman tertulis tentang mata pelajaran itu biasa pula dianggap kurikulum. Definisi lain diajukan Beauchamp
(1975) yang melihat kurikulum sebagai "document to be used as a point of departure in instructional planning". Di samping itu, Taba (1962) melihat kurikulum sebagai "plan for learning".

Konsep kurikulum sebagai materi pelajaran berkembang pada tahun dua puluhan sampai dengan awal tiga puluhan dengan munculnya tiga ketentuan, yaitu (1) kurikulum harus dilengkapi dengan pernyataan tentang objektif pengajaran dalam silabus, (2) silabus itu perlu diujicobakan di lapangan, dan (3) silabus itu perlu dievaluasi pelaksanaannya dan kemudian direvisi untuk perbaikan. Salah satu kelemahan dari konsep ini adalah belum kelihatan kaitan antar materi dengan mata pelajaran dengan peserta didik. Konsep ini kemudian berkembang terus dengan terbitnya buku Caswell dan Campbell. Menurut Gress (1968) kedua pakar ini 
ISSN: 1829-6750 Inovasi Kurikulum, Agustus 2009, Thn. 6. Vol 6 Nomor: 2

menemukan bahwa kesesuaian antara kurikulum formal dengan implementasinya di sekolah sedikit sekali.

Oleh karena itu mereka mengajukan kurikulum berupa pengalaman (learning experiences) yang benarbenar dimiliki peserta didik sebagai hasil implementasi dari kurikulum tertulis tersebut. Sejalan dengan pikiran ini, Zais (1976) mengemukakan bahwa "kalau kita mengevaluasi kurikulum, kita tidak cukup hanya mengevaluasi doku-men kurikulum itu saja, tetapi lebih dari itu mengevaluasi pengetahuan, keterampilan, sikap yang dimiliki peserta didik sebagai hasil dari implementasi kurikulum tertulis itu'. Kurikulum sebagai pengalaman belajar yang dirancang sekolah (planned learning experiences), merupakan konsep kurikulum yang banyak dianut para pakar pendidikan. Tetapi ada pula pakar yang menganggap bahwa pengertian kurikulum di atas terlalu luas, dan ada pula yang menganggap terlalu sempit.

Terlepas dari adanya pro dan kontra mengenai berbagai konsep kurikulum yang dipaparkan para pakar tersebut di atas, yang paling penting adalah bahwa pengalaman belajar peserta didik merupakan sesuatu yang dianggap paling relevan. Sebab konsep ini merupakan hasil langsung dari implementasi kurikulum sekolah, dan merupakan keinginan yang akan dicapai negara kita saat ini (baik kurikulum 2004 yang telah lalu maupun kurikulum 2006 sekarang ini). Walaupun begitu, para peserta didik menyadari, bahwa pengalaman yang diperolehnya di luar sekolah merupakan muatan yang tidak dapat diabaikan pada keberhasilan implementasi kurikulum formal. Kedua muatan kurikulum tersebut saling melengkapi dan saling 
ISSN: 1829-6750 Inovasi Kurikulum, Agustus 2009, Thn. 6 . Vol 6 Nomor: 2

menguatkan satu sama lain. Atas dasar inilah, mengapa selalu ada upaya perubahan dan penyempurnaan kurikulum kita.

Upaya itu patut dihargai, mengingat kondisi bangsa Indonesia saat ini sedang memasuki periode yang amat penting dalam rangkaian pembaharuan sistem pendidikan nasional. Usaha keras perlu dilakukan untuk meningkatkan kualitas lulusan pada setiap jenjang pendidikan dengan memperhatikan masalah keterkaitan dan kesepadanan. Untuk itu, diperlukan seperangkat kurikulum yang relevan dengan sistem pendidikan nasional dewasa ini.

Usaha untuk mengembangkan atau menyesuaikan kurikulum yang relevan dengan sistem pendidikan nasional, perlu diupayakan secara terus menerus. Minimal ada tiga alasan pokok mengapa usaha itu perlu dilakukan terus, yakni 1) adanya perubahan paradigma baru pendidikan; 2) adanya perubahan sosial budaya; ekonomi dan politik akibat pengaruh globalisasi, dan 3) tuntutan terhadap peningkatan kualitas lulusan yang sangat diperlukan bagi terwujudnya sumber daya manusia yang handal.

\section{B. Pembahasan}

\section{Konsep Kurikulum Tingkat Satuan Pendidikan (KTSP)}

Dengan digunakannya kurikulum $2006 \quad$ (KTSP), perubahan kurikulum 2004 ke 2006, merupakan upaya pembaharuan atau penyesuaian kurikulum yang didasarkan pada standar isi dan standar kompetensi lulusan yang diharapkan sejalan dengan kebutuhan masyarakat.

Lahirnya KTSP didasari oleh adanya Undang-undang Sisdiknas no. 20 tahun 2003 dan Peraturan Pemerintah no. 
ISSN: 1829-6750 Inovasi Kurikulum, Agustus 2009, Thn. 6 . Vol 6 Nomor: 2

19 tahun 2005 tentang Standar Nasional Pendidikan.

Disebutkan di dalamnya bahwa kurikulum pada dasarnya merupakan rencana pengaturan mengenai tujuan, isi, dan bahan pelajaran, serta cara yang digunakan sebagai pedoman penyelenggaraan kegiatan pembelajaran untuk mencapai tujuan pendidikan tertentu. Tujuan tersebut meliputi tujuan pendidikan nasional yang sesuai dengan kondisi dan potensi daerah, satuan pendidikan dan peserta didik.

Pengembangan kurikulum dalam KTSP pada intinya mengacu pada standar nasional pendidikan untuk menjamin pencapaian tujuan pendidikan nasional. Standar pendidikan nasional tersebut terdiri atas standar isi, proses, kompetensi lulusan, tenaga kependidikan, sarana dan prasarana, pengelolaan, pembiayaan, dan penilaian pendidikan.

KTSP pada jenjang pendidikan menengah (SMA,
MAN), disusun oleh satuan pendidikan dengan mengacu pada standar isi (SI) dan standar kompetensi lulusan (SKL), serta berpedoman pada panduan yang disusun oleh Badan Standar Nasional Pendidikan (BSNP). Tujuannya adalah meningkatkan kecerdasan, pengetahuan, kepribadian, akhlak mulia, serta keterampilan untuk hidup mandiri, dan dapat mengikuti pendidikan lebih lanjut.

Dalam Undang-undang Republik Indonesia no. 20 tahun 2003 tentang Sisdiknas pada Bab 11 Pasal 3 dijelaskan bahwa "Pendidikan nasional berfungsi mengembangkan kemampuan dan membentuk watak serta peradaban bangsa yang bermartabat dalam rangka mencerdaskan kehidupan bangsa, bertujuan untuk berkembangnya potensi peserta didik agar menjadi manusia yang beriman dan bertakwa kepada Tuhan Yang Maha Esa, berakhlak mulia, 
ISSN: 1829-6750 Inovasi Kurikulum, Agustus 2009, Thn. 6. Vol 6 Nomor: 2

sehat, berilmu, cakap, kreatif, mandiri, dan menjadi warga negara yang demokratis, serta bertanggung jawab".

Mengacu pada undangundang tersebut, KTSP dikembangkan berdasarkan pada prinsip-prinsip sebagai berikut: 1) berpusat pada potensi, perkembangan, kebutuhan, dan kepentingan peserta didik; 2) beragam dan terpadu; 3) tanggap terhadap perkembangan IPTEKS; relevan dengan kebutuhan kehidupan; 5) komprehensif dan ber-kesinambungan; belajar sepanjang hayat (life long education); 7) seimbang antara kepentingan nasional dan kepentingan daerah.

Sedangkan komponen-komponen KTSP meliputi: tujuan pendidikan tingkat satuan pendidikan; b) struktur dan muatan kurikulum; dan c) kalender pendidikan.

Khusus untuk KTSP tingkat pendidikan menengah (SMA), tujuan pendidikannya adalah meningkatkan ke-cerdasan, pengetahuan, ke-pribadian, akhlak mulia, serta keterampilan untuk hidup mandiri, dan dapat mengikuti pendidikan lebih lanjut. Struktur dan muatan kurikulum mencakup sejumlah kelompok mata pelajaran, yakni mata pelajaran agama dan akhlak mulia, kewarganegaraan dan kepribadian, ilmu pengetahuan dan teknologi, estetika, dan mata pelajaran jasmani, olah raga dan kesehatan. Mata pelajaran beserta alokasi waktu berpedoman pada struktur kurikulum yang tercantum dalam standar isi. Sementara muatan lokal merupakan kegiatan kurikuler untuk mengembangkan kompetensi yang disesuaikan dengan ciri khas dan potensi daerah. Hal-hal lainnya berkenaan pula dengan kegiatan pengembangan diri, peng-aturan beban belajar, ketuntasan belajar, kenaikan kelas dan kelulusan, penjurusan, pendidikan kecakapan hidup, dan 
ISSN: 1829-6750 Inovasi Kurikulum, Agustus 2009, Thn. 6 . Vol 6 Nomor: 2

pendidikan berbasis keunggulan lokal dan global.

Pada tataran implementasi kurikulum, implementasi KTSP (kurikulum 2006) pada dasarnya adalah pengembangan silabus, pelaksanaan proses pembelajaran, sistem penilaiannya.

Silabus merupakan rencana dan pedoman untuk melaksanakan pembelajaran.

Proses dilaksanakan dengan menerapkan prinsip-prinsip pembelajaran dan standar proses pendidikan yang disarankan oleh Badan Nasional Sstandar Nasional (BNSP). Sedangkan sistem penilaian mencakup jenis ujian, bentuk soal dan pelaksanaannya. Tingkat keberhasilan yang dicapai peserta didik dilihat pada kemampuannya dalam menyelesaikan tugas-tugas yang harus dikuasai sesuai dengan standar kompetensi dan prosedur tertentu.
Yang menjadi persoalan adalah bagaimana mengembangkan silabus pembelajaran di SMA agar sejalan atau sesuai dengan kebutuhan peserta didik dalam menghadapi masa depannya. Materi, strategi, media dan evaluasi seperti apa yang dibutuhkan dalam implementasi KTSP.

Ada beberapa hal yang harus dipertimbangkan dalam usaha mengimplementasikan kurikulum 2006 (KTSP) dengan berbagai kompetensi yang diharapkan.

Pertama, Dirjen Dikdasmen Dr. Indra Djati Sidi pernah menyampaikan pokok-pokok pikiran dalam tulisannya yang berjudul

"Mempertimbangkan Paradigma Baru Bagi Pendidikan". Ia menyarankan untuk masa depan agar para pendidik, demi perubahan dan tantangan zaman hendaknya dapat mengubah pola pikir dan perilaku dari mengajar (teaching) menjadi belajar (learning) yang berarti proses 
ISSN: 1829-6750 Inovasi Kurikulum, Agustus 2009, Thn. 6. Vol 6 Nomor: 2

pendidikan yang dijalankan selama ini berubah menjadi "proses bagaimana belajar bersama antara guru dan peserta didik".

Kedua, apa yang disampaikan oleh komisi internasional tentang pendidikan abad XXI yang dilaporkan pada UNESCO dengan topik "Belajar, Harta Karun di Dalamnya". Menurut M. Atar Semi (2000) komisi ini menegaskan bahwa pendidikan di masa yang akan datang harus dapat memampukan setiap orang menemukan, menggali, dan memperkaya potensi kreatif peserta didik untuk menyingkap harta karun yang ada dalam dirinya masingmasing.

Hal ini memberikan isyarat kepada kita bahwa untuk mengembangkan atau menyesuaikan kurikulum di masa depan, kita perlu melakukan perubahan arah pendidikan, yakni dari pendidikan sebagai suatu porses yang dihayati seseorang untuk meraih tujuan khusus (seperti memperoleh keterampilan untuk meningkatkan potensi ekonomis), ke arah pendidikan yang memfokuskan pembangunan manusia seutuhnya.

Pendidikan yang menekankan pada belajar menjadi seseorang, misi utamanya adalah memberdayakan peserta didik untuk mengembangkan bakat atau talenta, dan mewujudkan potensi kreatif untuk menjalani kehidupan serta meraih tujuan pribadi masing-masing. Dalam hubungan itu, pengembangan atau penyesuaian kurikulum hendaklah dapat menghasilkan manusia berketrampilan, berpikir teratur, sistematis dan runtut, guna membentuk sifat kreatif dan mandiri, serta memiliki kepekaan sosial atau peduli lingkungan, menghargai perbedaan budaya, terampil dan tanggungjawab pribadi. Artinya kurikulum yang 
ISSN: 1829-6750 Inovasi Kurikulum, Agustus 2009, Thn. 6 . Vol 6 Nomor: 2

dikembangkan atau disesuaikan itu harus dapat memberdayakan peserta didik untuk berpikir mandiri, kritis, dan dapat mengaplikasikan pengetahuan dan keterampilannya dalam kehidupan nyata sehari-hari.

Ketiga, belajar (learning) mengimplisitkan bahwa peserta didik akan sangat berperan dalam mencapai kompentensi yang dituntut darinya. Ia harus berperan aktif, dan guru bertindak sebagai fasilitator dan motivator, bukan lagi pemegang otoritas utama di kelas. Cara ini akan melahirkan peserta didik yang mandiri, kreatif, dan inovatif. "Pencekokan" teori dan penghafalan sudah harus ditinggalkan, kalau mau mengutamakan learning on learn.

Keempat, sasaran akhir lain dari penyempurnaan kurikulum adalah timbulnya perkembangan pribadi perserta didik. Perkembangan pribadi ini merupakan akumulasi dari seperangkat pengalaman belajar yang menyertai materi pelajaran. Implikasinya ialah bahwa materi pelajaran merupakan "means", bukan "ends" untuk mencapai tujuan yang lebih jauh, yaitu pengalaman peserta didik. Ini berarti bahwa pada tahap perencanaan kurikulum, materi pelajaran didesain untuk menimbulkan pengalaman belajar yang diinginkan.

Pada tahap pelaksanaan kurikulum, berbagai ragam kegiatan belajar juga didesain untuk menimbulkan pengalaman belajar. Untuk mengetahui sejauh mana efektivitas proses belajar pada diri siswa, pada tahap evaluasi dicek apakah semua pengalaman belajar yang direncanakan untuk peserta didik telah tercapai. Hal yang sering ditemukan di lapangan adalah bahwa pada tahap perencanaan, pelaksanaan, dan evaluasi, yang menjadi fokus perhatian adalah materi 
ISSN: 1829-6750 Inovasi Kurikulum, Agustus 2009, Thn. 6 . Vol 6 Nomor: 2

pengajaran. Hal ini menunjukkan bahwa tujuan pengembangan kurikulum adalah untuk membuat peserta didik menguasai materi pelajaran sebanyakbanyaknya, bukan membantu mentransformasikan materi pelajaran agar menjadi pengalaman belajar yang ingin dicapai.

Kelima, untuk mengimplementasikan kurikulum, diperlukan program pendidikan. Program itu terdiri atas (1) program studi yang memuat budaya yang perlu diwariskan (cultural heritage) dan pembekalan pengetahuan (store of knowledge), kegiatan belajar yang terdiri atas kegiatan-kegiatan peserta didik supaya apa yang mereka pelajari itu bermakna dan menjadi "milik" atau pengalaman mereka sendiri, dan (3) program bimbingan yang memberikan layanan kepada peserta didik agar tercapai kelancaran proses belajar-mengajar.
Keenam, setiap pengembangan dan pengajaran harus berupaya peduli terhadap empat komponen kurikulum, yaitu (1) tujuan yang ingin dicapai, (2) materi dan pengalaman belajar yang perlu diberikan agar tujuan itu tercapai, 3) metodologi yang sesuai dengan kebutuhan, dan (4) evaluasi yang dapat mengukur hasil belajar siswa, berupa materi pelajaran dan pengalaman belajar. Oleh karena itu, setiap merancang pengajaran, keempat komponen tersebut perlu diperhatikan dengan baik dan seksama.

\section{Bagaimana Mengevaluasi KTSP?}

Untuk melangkah maju ke arah evaluasi yang lebih tepat, sebaiknya keadaan di lapangan disurvey terlebih dahulu hal-hal yang berhubungan dengan: 1) karakterisitik peserta didik dan macam keterampilan atau pengetahuan yang dibutuh- 
ISSN: 1829-6750 Inovasi Kurikulum, Agustus 2009, Thn. 6. Vol 6 Nomor: 2

kan dan yang sudah dikuasai; 2) menyusun prototype silabus yang meliputi rincian materi pelajaran dan penggunaannya yang ingin diliput oleh silabus tersebut; kemudian 3) menyusun silabus materi pelajaran dan urutan tesnya beserta instrument yang akan digunakan.

Setelah itu, hendaknya dikembangkan prosedur kelas yang meliputi antara lain metode dan teknik mengajar, penyusunan satuan pelajaran dan rencana mengajar mingguan, kemudian ditutup dengan evaluasi terhadap siswa, program dan metode atau teknik mengajar untuk menjadi masukan perbaikan materi pelajaran, apakah cocok antara kemampuan dengan tujuan atau tidak? Bila tidak, maka dilakukan perbaikan atau penyesuaian materi atau metodologi seperlunya.

Langkah lain yang perlu diperhatikan dalam pengembangan kurikulum 2006
(KTSP) adalah rambu-rambu pembelajarannya. Misalnya pembelajaran ditujukan untuk apa, diarahkan ke mana, tema yang digunakan untuk mencapai sasarannya bagaimana, bobot pembelajaran seperti apa, dan bagaimana memilih gradasi (tingkatan) bahan agar sesuai dengan tema yang dipilih, dan lain sebagainya. Prinsip dasar dalam penentuan ramburambu pembelajaran, sebaiknya diatur sefleksibel mungkin sehingga memungkinkan setiap peserta didik maupun guru sebagai pengelola pembelajaran bisa berkreativitas.

\section{Penutup}

Penilaian (evaluasi) terhadap kurikulum memang merupakan suatu proses untuk mengambil keputusan dengan menggunakan data-data atau informasi yang diperoleh melalui hasil pengukuran, apakah sifatnya kuantitatif atau kualitatif. Maksud 
ISSN: 1829-6750 Inovasi Kurikulum, Agustus 2009, Thn. 6 . Vol 6 Nomor: 2

evaluasi adalah memberi "nilai" tentang kualitas sesuatu, tidak hanya sekedar mencari jawaban terhadap pertanyaan tentang apa; namun lebih diarahkan pada jawaban dari pertanyaan tentang "bagaimana atau seberapa jauh sesuatu proses atau hasil suatu program kurikulum (misalnya) dapat dicapai".

Dalam konteks pelaksanaan kurikulum, hasil penilaian dapat diamati melalui indikator-indikator yang tercermin dalam rangkaian kegiatan pembelajaran, sebagai bentuk implementasi kurikulum.

Untuk melihat sejauhmana keberhasilan dari implementasi kurikulum, sudah barang tentu membutuhkan waktu dan proses, karena hasil dari suatu proses pembelajaran merupakan rangkaian kegiatan yang terus menerus dan panjang. Karena itu evaluasi terhadap Kurikulum Tingkat Satuan Pendidikan (KTSP) seyogyanya di-lakukan setelah kurikulum tersebut berlangsung, paling tidak tiga sampai empat tahun. Dengan harapan semua satuan pendidikan sejak awal telah benar-benar mempersiapkannya.

\section{Daftar Pustaka}

Beuchamp, Georg A. , (1975), Curriculum Theory, Tihrd Edition, The Kagg Press, Illions.

Brown, James Dean, (1995), The Element of Language Curriculum, A Systematic Approach to Program Develop-ment, Heinle \& Heinle Publishers, U.S.A.

Depdiknas, (2004), Kurikulum Berbasis Kompetensi, Pendidikan Prasekolah, Dasar dan Menengah, Departemen Pendidikan Nasional, Jakarta.

Hasan, S. Hamid, (1988), Evaluasi Kurikulum, Departemen Pendidikan 
ISSN: 1829-6750 Inovasi Kurikulum, Agustus 2009, Thn. 6. Vol 6 Nomor: 2

dan Kebudayan Direktorat Jenderal Pendidikan Tinggi, Jakarta.

Miller, John P. \& Seller , Wayne, (1985), Curriculum, Perspective and Practice, Longman Inc. New York \& London.

Schubert, William H., Curriculum; Perspective, Paradigm, and Possibility, William H. Schubert, NewYork.

Syaodih, Nana Sukmadinata, (2002), Pengembangan Kurikulum, Teori dan Praktek, PT Remaja Rosdakarya, Bandung.

Willes, John \& Bondi, Joseph, (1989), Curriculum Develop-ment, A. Guide to Practice, Merrill Publishing Company, Columbus, Ohio.

Zais, Robert, S. (1976), Curriculum: Principles and Foundation, Harper \& Row Publisher, New York. 